\title{
Foreword
}

\section{R.M. Trüeb}

Department of Dermatology, University Hospital of Zurich, Zurich, Switzerland

Throughout history, human hair has been the object of cosmetic and medical interest as well as of superstition and mystery. As early as can be traced, written documents testify to endeavours of mankind to please by means of the hair. Nevertheless, only recently have we been witnessing substantial advances in the understanding of hair biology and its pathological conditions. Continuous progress is being made at a high pace thanks to the impetus of a generation of astute clinical trichologists and basic scientists interested in hair biology, the powerful tools of molecular biology and innovative technologies. The European Hair Research Society (EHRS) aims at bringing together enthusiastic colleagues from all over the world for the exchange and discussion of the latest highlights in hair research and clinics. At the 2005 EHRS Meeting, on July 7-9 in Zurich, Switzerland, distinguished international speakers and young scientists gathered to present up-to-date knowledge on important topics of current hair research, such as gerontobiology of the hair follicle, hair pigmentation, neurobiology of the hair follicle, psychosomatics of hair, hair follicle immunology, genetics of hair and progress in stem cell and tissue engineering research.

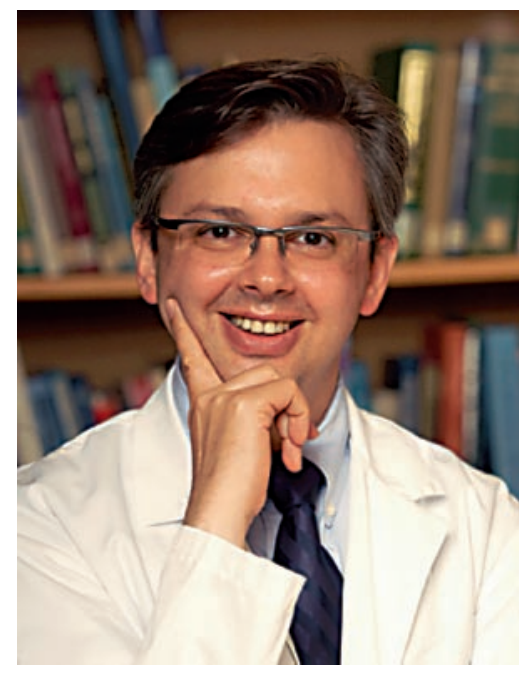

It is my pleasure to present here the abstracts of the meeting. I would like to thank the EHRS Scientific Committee, who carefully selected the abstracts for presentation, and Karger for publishing them in this special issue of Dermatology.

R.M. Trüeb, Congress President

\section{KARGER}

Fax +4161306 1234 E-Mail karger@karger.ch www.karger.com
(C) 2005 S. Karger AG, Basel

$1018-8665 / 05 / 2111-0005 \$ 22.00 / 0$

Accessible online at: www.karger.com/drm 